\title{
Eclogite Xenoliths from the kimberlites of the Eastern Dharwar Craton, South India: material representing ancient crust of the Western Dharwar Craton?
}

\author{
E.V.S.S.K. Babu ${ }^{1,2, *}$, W.L. Griffin ${ }^{1}$, S. Panda ${ }^{2}$, S.Y. O’Reilly ${ }^{1}$, Y.J. Bhaskar Rao ${ }^{2}$ \\ ${ }^{1}$ ARC National Key Centre GEMOC, Macquarie University, NSW 2109, Australia \\ ${ }^{2}$ National Geophysical Research Institute, Uppal Road, Hyderabad-500007, India \\ *e-mail: evsskbabu@yahoo.co.in
}

\section{Introduction}

Eclogites, sensu stricto are bimineralic rocks of pyrope and omphacite equilibrated under uppermantle temperature and pressures. However, they could represent a range of protoliths such as picritic basalts crystallized in magma chambers within the mantle, subducted ocean floor or delaminated lower crustal material. Such heterogeneity from a suite of eclogite xenoliths brought by explosive kimberlite volcanism can often be identified through their constituent mineralogy and compositions.

Here we present a set of new mineralogical, thermobarometric and geochemical data on kimberliteborne eclogitic xenoliths from the Eastern Dharwar Craton (EDC), south India to speculate on their possible protoliths and their geodynamic significance in the light of an ongoing debate on the crustal and lithospheric architecture of the Dharwar Craton (Figure 1 ). Based on the lithological variations, nature of volcano-sedimentary sequences, magmatic character, geochronological data, metamorphic grade and geophysical properties the Dharwar Craton is divided into distinct Eastern and Western domains (Refs.Chadwick et al. 2000; Chadwick et al. 2007; Jayananda et al. 2000; Gupta et al. 2003 and references cited therein). Current tectonic models visualize a Neoarchaean oblique convergence of the WDC and EDC. Implicit is that the older WDC crust underlies a tectonic stack of west-verging EDC (Chadwick et al. 2007). A prominent zone of mylonites straddles the eastern margin of the Chitradurga schist belt in the WDC and the ca $2.5 \mathrm{Ga}$ Closepet granite complex is proximal to this mylonite zone. The eastern margin of this accretion zone also localised several clusters of $\sim$ 1.1. Ga kimberlite pipes (Anil Kumar et al. 2007). These kimberlites entrained diverse eclogite xenolith suits representing a variety of protoliths. This work assumes significance in tracing the xenoliths to protoliths and find possible genetic linkages with the cospatial TTG gneisses of the terrain.

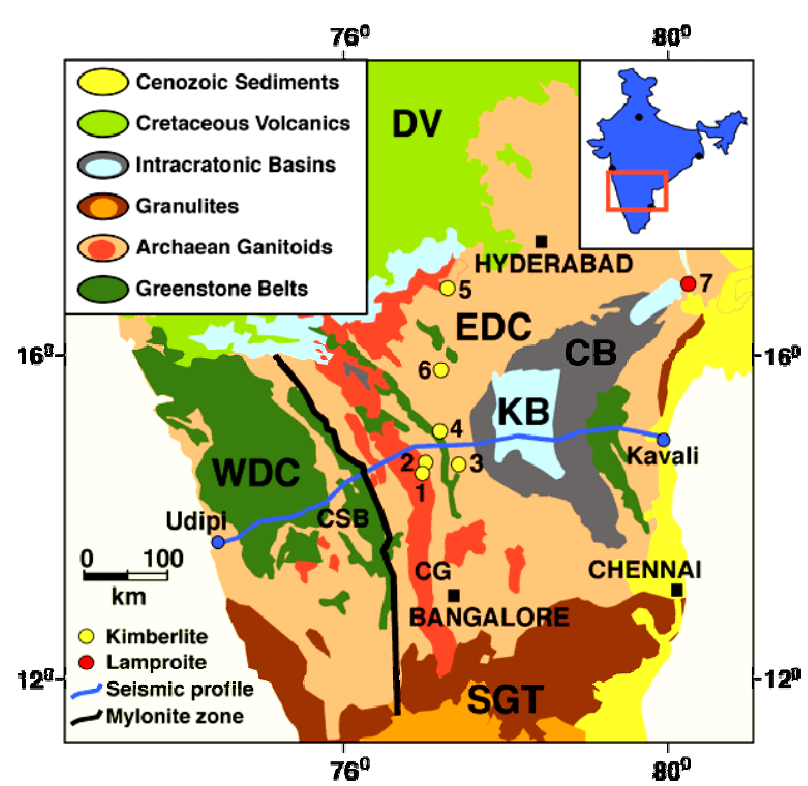

Figure 1. Location of the major kimberlite and lamproite clusters of the Dharwar craton, south India. 1. Kalyandurg, 2. Brahmanaplly, 3. Chigicheral, 4. Wajrakarur, 5. Mahaboobnagar, 6, Raichur, 7. Krishna Lamproite field. EDC-Eastern Dharwar Craton, WDC-Western Dharwar Craton, CSB-Chitra Durga Shear Belt, DV-Deccan Volcanics, SGT-Southern Granulite Terrain, CG-Closepet Granite.

\section{Materials and Methods}

The eclogite types include bimineralic and kyanite-coesite-rutile-bearing varieties with the former restricted to the Wajrakarur cluster. Some of the kyanite-coesite bearing eclogites (Figure 2) show alteration zones with traces of celsian, hyalophane and barite suggesting extensive Ba metasomatism.

A new class of prehnite-bearing eclogites was also identified suggesting post kimberlite emplacement low-temperature alteration of the eclogite xenolith. Some of the eclogite xenoliths also have both intracrystalline primary base metal sulphides as well as secondary sulphide veins. 


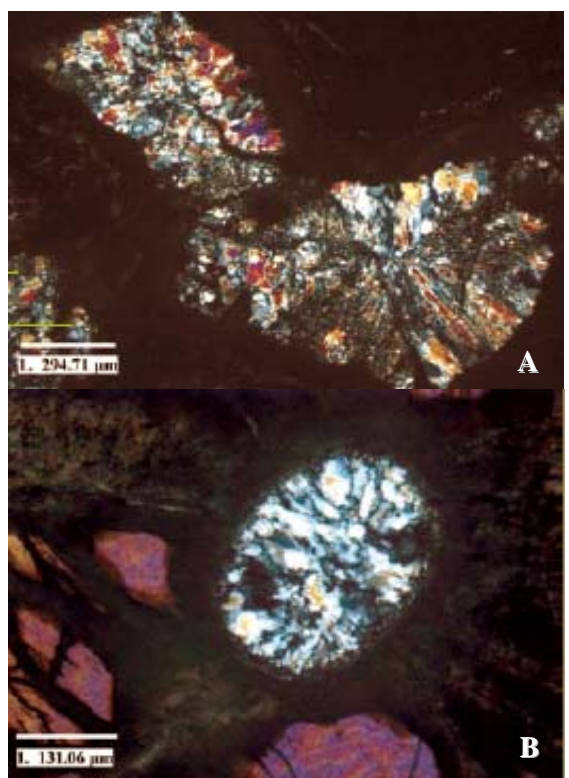

Figure 2. A. Coesite-bearing and B. Kyanite-coesitebearing eclogite xenoliths.

\section{Thermobarometry}

Temperature estimates based on the conventional thermometry using the garnet and clinopyroxene were projected on to the xenolith geotherms of different kimberlite clusters. Kalyandurg xenoliths fall on a typical Archaean geotherm with a 35 $\mathrm{mW} / \mathrm{m}^{2}$ and those from the Wajrakarur represent a 40 $\mathrm{mW} / \mathrm{m}^{2}$ Proterozoic geotherm.

The eclogite xenoliths from the Wajrakarur kimberlite cluster shows P-Ts ranging from 750$1225^{\circ} \mathrm{C}$ and $29-61 \mathrm{kbar}$ with a wide depth distribution (Figure 3). Whereas, the xenoliths from the Kalyandurg cluster are restricted to a narrow range of $1020-1185^{\circ} \mathrm{C}$ and 56-61 kbar corresponding to a single layer corresponding to a depth of 176-191 km (figure 3).

Although eclogites from the Kalyandurg cluster show marked distribution of mineralogical variations, their depth distribution is confined to a 10 $20 \mathrm{~km}$ layer between 176-191 km. This feature is similar to that seen in many SCLM sections (see Griffin and O’Reilly, 2007) The studies on garnet xenocrysts from these clusters (see 9IKC-A-00103 by Griffin et al. in this abstract volume) further puts constraints on the nature of Indian Sub continental lithospheric mantle (SCLM) at this depth at $~ 1.1 \mathrm{Ga}$. The presence of eclogite layers in the SCLM also show correspondence with the pyropic garnet trace element signatures at the corresponding depths.
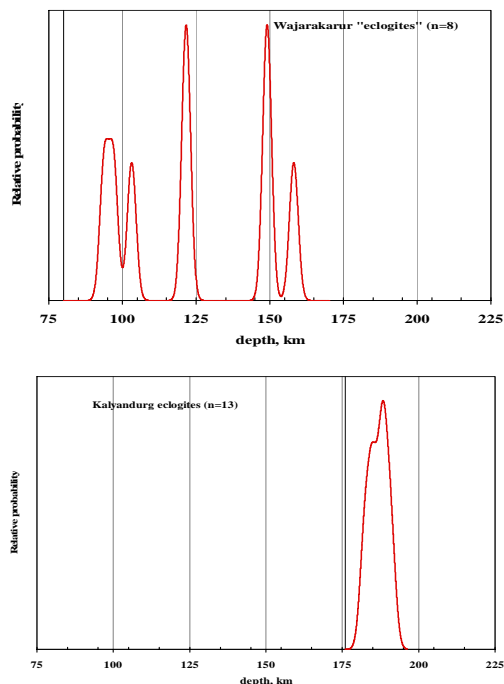

Figure 3. Relative probability vs. depth distribution for eclogite xenoliths from the Wajrakarur and Kalyandurg Kimberlite clusters. The depth distribution was arrived after projecting the estimated pressures and temperatures from conventional thermobarometry on to the xenolith geotherm.

\section{Major and Trace element geochemistry}

35 petrographically distinct eclogites were analysed for mineral and bulk chemical compositions. They are characterized by low MgO (5.3-12.15 wt. \%), high $\mathrm{Al}_{2} \mathrm{O}_{3}(14.75-26.22 \%)$ and $\mathrm{CaO}$ (11.14 to 28.12 $\%)$. High $\mathrm{MgO}$ eclogites were observed from only the Wajrakarur cluster. Whereas, the eclogites from the Kalyandurg cluster show lower bulk MgO contents.

Among the trace element abundances the most enriched elements are $\mathrm{Ba}$ (309-9270 ppm) and $\mathrm{Sr}$ (2220-15823 ppm) with minor enrichment of Rb (0.7$145 \mathrm{ppm})$. Most of the bimineralic eclogites show flat REE patterns. In contrast, kyanite-bearing types show pronounced +ve Eu anomalies with LREE-enriched and HREE depleted patterns; these anomalies are also seen in the cpx and gnt. High field strength element abundances vary with the abundance of accessory rutile. The major and trace element compositions such as low $\mathrm{MgO}$, high $\mathrm{Al}_{2} \mathrm{O}_{3}$ and $\mathrm{CaO}$, presence of $\mathrm{Eu}$ anomalies in bulk rock analyses and individual minerals suggest altered crustal protoliths.

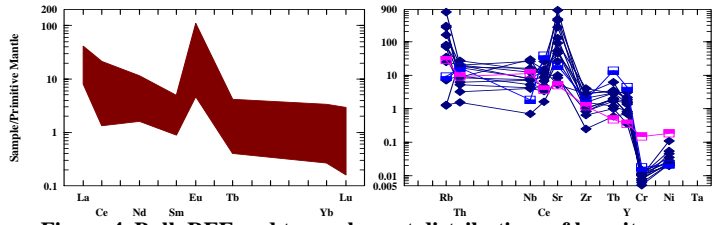

Figure 4. Bulk REE and trace element distributions of kyanite eclogite xenoliths from the Kalyandurg. 


\section{Conclusions}

(1) Eclogite xenoliths from the S. Indian kimberlite pipes could represent a variety of protoliths.

(2) Wajrakarur and Kalyandurg clusters entrain kimberlites from distinct horizons of the Subcontinental Lithospheric Mantle sections.

(3) High Mg\# bimineralic deeper eclogites could possibly represent picritic trapped melts. Whereas, the low Mg\# kyanite-coesite eclogites represent crustally derived protoliths or picritic sources severely altered by crustal components.

(4) The crustal component observed in the eclogite xenoliths could possibly be derived from the WDC.

(5) The eclogite xenoliths show extensive $\mathrm{Ba}$ metasomatism with the presence of baryte and rarely celsian.

(6) Prehnite eclogites further suggests postentrainment alteration.

\section{References}

Anil Kumar, Heaman, L.M. and Manikyamba, C. 2007. Mesoproterozoic kimberlites in south India: A possible link to $\sim 1.1 \mathrm{Ga}$ global magmatism. Precambrian Research. Volume 154, pp. 192-204.

Chadwick, B., Vasudev, V.N. and Hegde, G.V. (2000) The Dharwar craton, southern India, interpreted as the result of Late Archaean oblique convergence. Precambrian Research. V. 99, pp. 91-111.

Chadwick, B., Vasudev, V.N., Hegde, G.V. and Nutman, A.P. Structure and SHRIMP U/Pb Zircon ages of granites adjacent to the Chitradurga Schist Belt: Implications for Neoarchaean convergence in the Dharwar Craton, Southern India. Journal of the Geological Society of India. v. 69. pp. 5-24.

Griffin, W.L. and O’Reilly, S.Y., 2007. Cratonic lithospheric mantle: Is anything subducted? Episodes. V. 30, pp. 43-53.

Griffin, W.L., Kobussen, A. F., Babu, E.V.S.S.K., O'Reilly, S.Y., Norris, R. and Sengupta, P. 2008. Contrasting lithospheric mantle across the suture between the Eastern and Western Dharwar Cratons, central India. Proceedings of the 9th International Kimberlite conference. Extended Abstract No. 9IKC-A-00103, Frankfurt, Germany. 10-15 August, 2008.

Gupta, S., Rai, S.S., Praksam, K.S., Sirnagesh, D., Bansal, B.K., Chadha, R.K. Priestley, K. and Gaur, V.K. (2003) The nature of the crust in southern India: Implications for Precambrian crustal evolution, Geophysical Research Letters, V. 30. No. 8, 1419, doi:10.1029/2002GL016770.
Jayananda, M., Moyen, J-F., Martin, H., Peucat, J-J., Auvray, B. and Mahabaleshwar, B. (2000) Late Archaean (2550$2520 \mathrm{Ma}$ ) juvenile magmatism in the Eastern Dharwar Craton, southern India : constraints from geochronology, $\mathrm{Nd}-\mathrm{Sr}$ isotopes and whole rock geochemistry. Precambrian Research. V. 99. pp. 225-254. 